\title{
AZ ISKOLAI VÉGZETTSÉG ÉS A MÁSODIK GYERMEKVÁLLALÁS BIZONYÍTÉKOK AZ ÉLETÜNK FORDULÓPONTJAI ADATBÁZISBÓL
}

\section{Bartus Tamás}

\section{ÖSSZEFOGLALÓ}

A korábbi kutatási eredmények szerint a nők iskolai végzettsége és a második gyermekvállalás között U alakú kapcsolat van Magyarországon. Ez a megfigyelés azonban ellentmond az elméleti várakozásoknak és a nemzetközi tapasztalatoknak. Két kérdésre keressük a választ: (1) Hogyan befolyásolja az anya iskolai végzettsége a második gyermekvállalás valószínűségét? (2) Értelmezhető-e a kapcsolat oksági kapcsolatként? Azaz, akkor is fennáll-e a kapcsolat, ha kiszürjük a minta szelektív összetételéből fakadó torzításokat, az időprés-hatást és a partner iskolai végzettségéből fakadó hatásokat. A kérdéseket az Életünk fordulópontjai panelvizsgálat 1-3. hullámaiból összeállított eseménytörténeti adatbázison vizsgáljuk. A diszkrét eseménytörténeti elemzés során szimultán becslésekkel kontrolláljuk a szelekciós torzítást. Eredményeink megerősítik a korábbi hazai kutatások eredményeit: az iskolázottság és a második gyermekvállalás összefüggése tényleg $U$ alakú. Az összefüggés valódi oksági kapcsolatnak tűnik, mivel az nem magyarázható sem szelekcióval, sem az időprés-hipotézissel, sem a partnerhatás-hipotézissel. Ha a párok iskolai végzettségét összevontan vizsgáljuk, azt találjuk, hogy a második gyermekvállalás valószínűsége egyrészt a legfeljebb 8 általános iskolát végzett nők, másrészt a diplomás párok között a legmagasabb.

Tárgyszavak: termékenység, iskolai végzettség, Életünk fordulópontjai, eseménytörténeti elemzés

Bartus Tamás, Budapesti Corvinus Egyetem, Szociológia és Társadalompolitika Intézet E-mail: tamas.bartus@uni-corvinus.hu 


\section{BEVEZETÉS}

A termékenységgel kapcsolatos hazai és nemzetközi kutatások viszonylag kevés figyelmet szenteltek annak a kérdésnek, hogyan befolyásolja az iskolai végzettség a második gyermekek megszületését. A korábbi magyarországi kutatások (Husz 2006, Spéder 2006, Bartus et al. 2013) szerint a második gyermeket legkisebb eséllyel a középfokú végzettségű nők vállalják. Szintén U alakú összefüggésről számolnak be azok a nemzetközi összehasonlító kutatások, amelyek során magyar adatokat is elemeztek (Klesment et al. 2014, Wood - Neels - Kil 2014). Az U alakú összefüggés aggregált szinten is érvényesül. A 2011-es népszámlálás adataiból rekonstruálható az 1931-1971 között született nők termékenysége. Ahogy az 1. ábra mutatja, a diplomások befejezett termékenysége csak kismértékben marad el az érettségizett nőkétől. A 2. ábra azt mutatja, hogy a második gyermekvállalás tekintetében felcserélődik az érettségizett és a dipIomás nők sorrendje az 1960 után (valamint a második világháború előtt) született nők körében. Sőt, az 1970-ben született diplomás nők majdnem utolérték a szakmunkás végzettséggel rendelkező nőkre jellemző valószínűséget.

1. ábra: A nök befejezett termékenysége iskolai végzettség és születési év szerint Completed fertility of women by educational level and year of birth

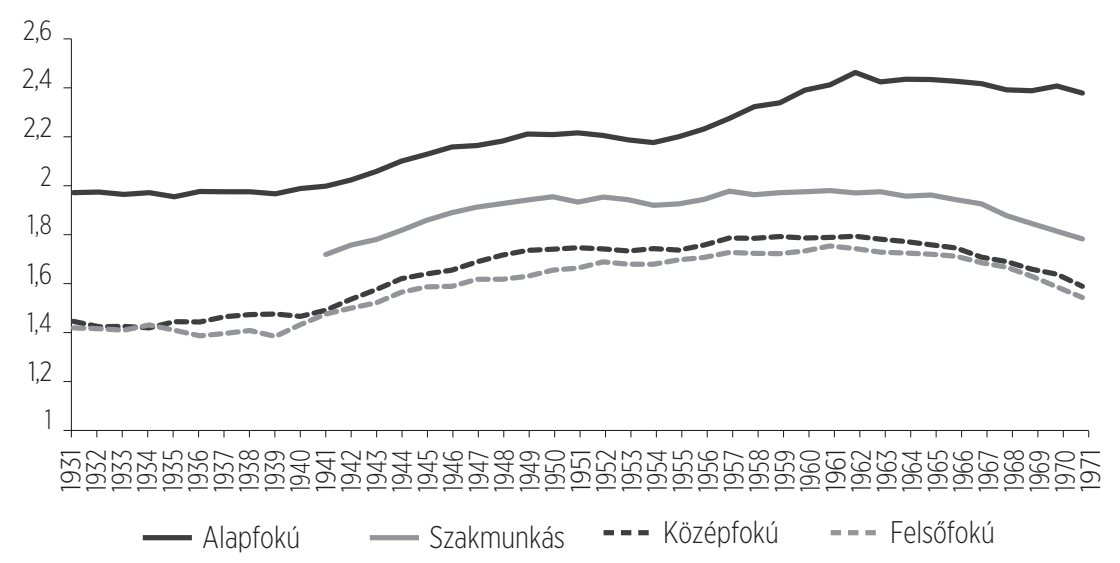

Forrás: a http://www.cfe-database.org honlapon keresztül elérhető 2011-es Népszámlálás adatai. (Letöltés: 2016.12.21.)

A magyar eredmények számottevően eltérnek azoktól a nemzetközi eredményektől, amelyek szerint a második gyermekvállalás esélye az iskolai végzettség monoton növekvő vagy csökkenő függvénye (Kreyenfeld 2002, Gerster et 
al. 2007, Beaujouan - Solaz 2008, Klesment - Puur 2010, Mureșan - Hoem 2010, Billingsley 2011, Wood - Neels - Kil 2014). Az U alakú minta ráadásul nem illeszkedik a termékenység magyarázatához használt elméletekhez, amelyekből monoton növekvő vagy csökkenő minta vezethető le. Például a közgazdasági elmélet szerint az összefüggésnek negatívnak kell lennie, feltéve, hogy a gyermeknevelés időigényes (Jones et al. 2011). Ráadásul az iskolázottsággal együtt javulnak a karrierkilátások, a karrier megszakításával járó jövedelem-kiesés tehát az iskolázottabbak számára jelent nagyobb veszteséget (Mincer - Polachek 1974, Happel - Hill - Low 1984, Montgomery - Trussel 1986, Taniguchi 1999, Gustafsson 2001). A másik népszerü termékenységelméletből, a második demográfiai átmenet elméletéből is negatív összefüggés vezethető le, mivel a termékenységgel és a családdal kapcsolatos posztmaterialista nézetek kialakulása a diplomások körében a legvalószínúbb (van de Kaa 2001).

2. ábra: A nök második gyermekvállalási valószinüsége iskolai végzettség és születési év szerint Second birth total cohort fertility rates of women by educational level and year of birth

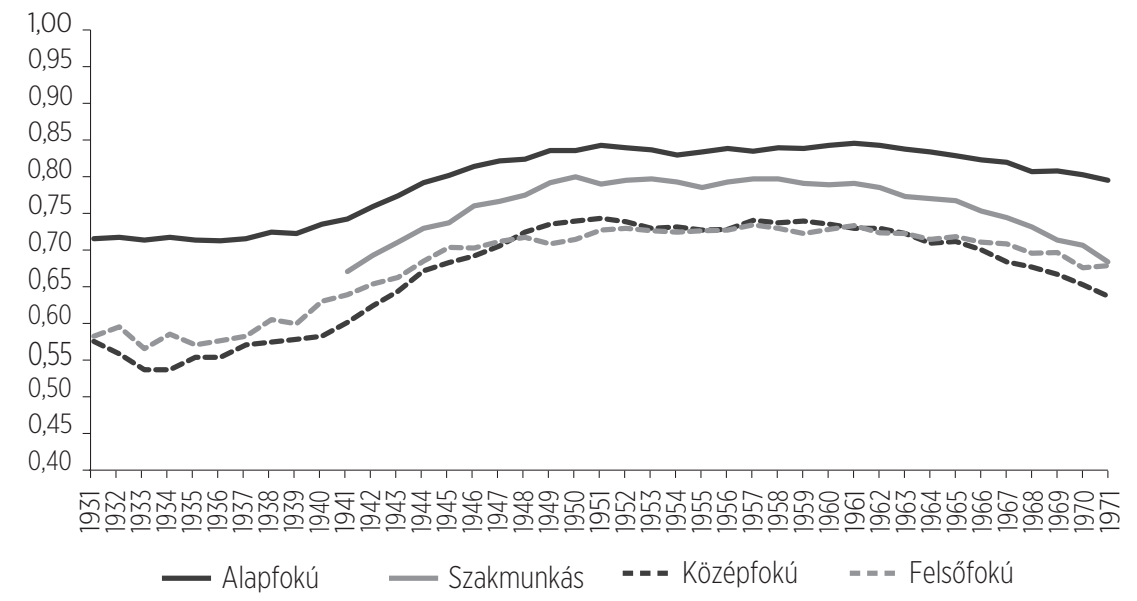

Forrás: a http://www.cfe-database.org honlapon keresztül elérhető 2011-es Népszámlálás adatai. (Letöltés: 2016.12.21.)

A második gyermekvállalást vizsgáló kutatásokban az a kérdés is felmerült, értelmezhető-e egyáltalán oksági kapcsolatként az iskolázottság és a második gyermekvállalás pozitív összefüggése. Kravdal (2001) amellett érvelt, hogy a pozitív összefüggés valójában módszertani artefaktum, és az elemzéshez szükséges minta szelektív összetételéből fakad. Kreyenfeld (2002) két további alternatív magyarázatot azonosított. Az egyik az időprés-mechanizmus: az első szülést 
késői életkorra időzítő diplomás nők közelebb állnak a termékeny életkor végéhez, ezért sietniük kell a második gyermekvállalással. A másik a partnerhatáshipotézis, amely szerint az iskolázott nők rendszerint iskolázott férfiakkal kötnek házasságot, az iskolázott férfiak magas keresete pedig lehetővé teszi akár több gyermek felnevelését is (Becker 1981, Kalmijn 1998, Kreyenfeld 2002). A hipotézis abból indul ki, hogy a gyermekvállalás a férfi partner iskolázottságának növekvő függvénye, hiszen az iskolázottabb, tehát többet kereső férfiak jövedelme teszi lehetővé az akár több gyermek felnevelését. A hipotézis viszont nem kötelezi el magát amellett, hogy a női iskolázottság hatást gyakorolna a gyermekvállalásra. Ennek oka, hogy a közgazdasági elméleten belül a női munkajövedelem ugyan csökkenti a gyermekvállalás pénzbeli költségeit, viszont növeli az időköltséget és a karrier megszakitásából fakadó veszteségeket. Az U alakú összefüggés levezetéséhez szükség van egy második feltevésre is: a diplomás partner jelenléte a női iskolázottság növekvő függvénye. A partnerhatás-hipotézis alapján tehát azt várjuk, hogy a női iskolázottság és a második gyermekvállalás közti kapcsolat eltűnik a hasonló végzettségű partnerrel rendelkező nők körében. Egyes kutatási eredmények azonban azt mutatják, hogy a nők iskolai végzettsége akkor is pozitív hatást gyakorol a második gyermek vállalására, ha kontrollálják a férfi partner iskolai végzettségét (Klesment - Puur 2010, Bartus et al. 2013).

Jelen tanulmány az Életünk fordulópontjai panelvizsgálat 1-3. hullámaira támaszkodva vizsgálja az iskolai végzettség és a második gyermekvállalás összefüggését. Két kérdésre keressük a választ: (1) Hogyan befolyásolja az anya iskolai végzettsége a második gyermekvállalás valószínűségét? (2) Értelmezhető-e a kapcsolat oksági kapcsolatként? Azaz, akkor is fennáll-e a kapcsolat, ha kiszűrjük a minta szelektív összetételéből fakadó torzításokat, az időprés-hatást és a partner iskolai végzettségéből fakadó hatásokat. Ezeket a kérdéseket Bartus és szerzőtársai (2013) már vizsgálták, a jelen tanulmány célja tehát az ott közölt eredmények replikálása. Az elemzés megismétlését módszertani megfontolások indokolják. Egyrészt Bartus és szerzőtársai a hazárdráta időbeni alakulásával kapcsolatban erős feltevéseket megfogalmazó, és ritkán használt lognormális modelleket becsültek. Másrészt magyarázó változóik időben állandók voltak. Jelen tanulmányban a sztenderdnek tekinthető diszkrét eseménytörténeti elemzést használjuk, időben változó magyarázó változókkal. Emellett a becslés során az Életünk fordulópontjai adatbázishoz készített súlyokat is használjuk, melynek célja a panelkopásból fakadó esetleges torzítások korrigálása (Bartus 2015). 


\section{ADATOK, VÁLTOZÓK ÉS LEÍRÓ ELEMZÉSEK}

Az elemzéshez az Életünk fordulópontjai felvétel 1-3. hullámaiból kialakított eseménytörténeti adatbázist használtuk. Az eseménytörténeti adatbázis személyhónap szerkezetü, és a szülésekre, a párkapcsolatok kialakulására és felbomlására, valamint az iskolatörténetre vonatkozó retrospektív információkon alapul. A partnerhatás-hipotézis tesztelése miatt a partner iskolai végzettségére is szükség van - ez az információ azonban csak keresztmetszeti információként jelenik meg az adatbázisban. A partner iskolai végzettsége viszont összekapcsolható azon személy-hónapokkal, melyek a keresztmetszetben (tehát az első, a második vagy a harmadik lekérdezés idején) fennálló párkapcsolathoz tartoznak.

Az elemzést az 1946-1975 között született nőkre korlátozzuk, és az 1962-2008 közötti időszakot fogja át. Az adathiányt tartalmazó megfigyelések kizárása után a minta 3354 főt tartalmaz. A függő változó a második teherbeesés esemény. Az egyszerüség kedvéért azonban végig második gyermekvállalásként hivatkozunk erre az eseményre.

A legfontosabb magyarázó változó az iskolai végzettség. Az iskolai végzettség az időben változó, dinamikus változó, amely az adott periódusra vonatkozó legmagasabb iskolai végzettséget jelöli (és nem a 3. hullám idején bevallott legmagasabb iskolai végzettséget). A változónak négy kategóriája van: alapfokú (nem végzett iskolát, vagy legfeljebb 8 általános iskolai osztályt végzett), szakmunkásképző, középfokú és felsőfokú.

A partner iskolai végzettségét szintén ezzel a négy kategóriával ragadtuk meg. Ez a változó időben állandó, és a partner legmagasabb végzettségét tartalmazza. Ennek oka, hogy az információk keresztmetszetiek, és a partner iskolatörténetét nem kérdezték le. Ha két tetszőleges hullám között nem történt változás a párkapcsolatban, de változott a partner végzettsége, akkor a magasabb értéket vettük figyelembe.

Kontrollváltozóként az iskolai részvételt, az életkort és a születési évet használjuk. Mindhárom változó dinamikus. Az iskolai részvétel dummy: értéke 1, ha az egyén az adott időpontban tanul; különben az értéke nulla.

A változók leíró statisztikáit az 1. táblázat tartalmazza. A személy-hónap adatbázis-szerkezet miatt a szülések ritkák: előfordulási gyakoriságuk 9 ezrelék a teljes mintában. Az iskolai végzettség változó leggyakoribb kategóriája az érettségi, legritkább kategóriája a felsőfokú végzettség. Az iskolai részvétel is ritka, 4,5\%-os gyakorisággal fordul elő. 
1. táblázat: Az elemzéshez használt változók leíró statisztikái

Descriptive statistics of variables used during data analysis

\begin{tabular}{|c|c|c|c|c|}
\hline \multirow{2}{*}{ Változó } & \multicolumn{2}{|c|}{ Teljes minta } & \multicolumn{2}{|c|}{ Párkapcsolatban élő nők } \\
\hline & átlag & szórás & átlag & szórás \\
\hline Második gyermekvállalás indikátor & 0,009 & 0,092 & 0,010 & 0,101 \\
\hline \multicolumn{5}{|l|}{ Iskolai végzettség } \\
\hline alapfokú & 0,218 & 0,413 & 0,193 & 0,394 \\
\hline szakmunkás & 0,244 & 0,429 & 0,219 & 0,413 \\
\hline középfokú & 0,370 & 0,482 & 0,405 & 0,491 \\
\hline felsőfokú & 0,166 & 0,372 & 0,181 & 0,385 \\
\hline \multicolumn{5}{|l|}{ Partner iskolai végzettsége } \\
\hline alapfokú & 0,070 & 0,256 & 0,070 & 0,256 \\
\hline szakmunkás & 0,476 & 0,499 & 0,476 & 0,499 \\
\hline középfokú & 0,299 & 0,457 & 0,299 & 0,457 \\
\hline felsőfokú & 0,153 & 0,360 & 0,153 & 0,360 \\
\hline \multicolumn{5}{|l|}{ Pár iskolai végzettsége } \\
\hline alapfokú - parneré ugyanaz & 0,045 & 0,207 & 0,045 & 0,207 \\
\hline alapfokú - parneré magasabb & 0,148 & 0,355 & 0,148 & 0,355 \\
\hline szakmunkás - parneré alacsonyabb & 0,013 & 0,113 & 0,013 & 0,113 \\
\hline szakmunkás - parneré ugyanaz & 0,152 & 0,359 & 0,152 & 0,359 \\
\hline szakmunkás - parneré magasabb & 0,053 & 0,224 & 0,053 & 0,224 \\
\hline középfokú - parneré alacsonyabb & 0,187 & 0,390 & 0,187 & 0,390 \\
\hline középfokú - parneré ugyanaz & 0,160 & 0,366 & 0,160 & 0,366 \\
\hline középfokú - parneré magasabb & 0,058 & 0,233 & 0,058 & 0,233 \\
\hline felsőfokú - parneré alacsonyabb & 0,093 & 0,290 & 0,093 & 0,290 \\
\hline felsőfokú - parneré ugyanaz & 0,088 & 0,283 & 0,088 & 0,283 \\
\hline Tanul & 0,047 & 0,213 & 0,045 & 0,208 \\
\hline életkor-15 & 30,716 & 7,975 & 30,537 & 7,781 \\
\hline log (életkor-14) & 2,688 & 0,531 & 2,685 & 0,510 \\
\hline születési év & 1962,164 & 7,764 & 1963,130 & 7,737 \\
\hline
\end{tabular}

Megjegyzés: súlyozott becslések az Életünk fordulópontjai felvétel adataiból kialakitott eseménytörténeti adatbázison.

A 2. táblázatban foglaltuk össze a második szüléssel kapcsolatos mutatók eloszlásait. A hazárdráta - pontosabban az ezer nőre jutó szülések száma mellett az események és a hónapok számát is feltüntetjük. A teljes mintában ezer nőre durván 9 szülés jut havonta. A második gyermekvállalás hazárdrátája az érettségizettek körében a legalacsonyabb és az alapfokú végzettségüek között a legmagasabb. A diplomásokra jellemző ráta a második legmagasabb. 
2. táblázat: A második gyermekvállalás eloszlása a magyarázó változók szerint Distribution of second births by explanatory variables

\begin{tabular}{|c|c|c|c|c|c|c|}
\hline \multirow{2}{*}{ Változó } & \multicolumn{3}{|c|}{ Teljes minta } & \multicolumn{3}{|c|}{ Partnerminta } \\
\hline & $\begin{array}{l}\text { Hazárdráta } \\
\text { (X1000) }\end{array}$ & $\begin{array}{l}\text { Események } \\
\text { száma }\end{array}$ & $\begin{array}{l}\text { Hónapok } \\
\text { száma }\end{array}$ & $\begin{array}{l}\text { Hazárdráta } \\
\text { (X1000) }\end{array}$ & $\begin{array}{l}\text { Események } \\
\text { száma }\end{array}$ & $\begin{array}{l}\text { Hónapok } \\
\text { száma }\end{array}$ \\
\hline Teljes minta & 9,4 & 2059 & 218278 & 10,4 & 1320 & 126033 \\
\hline \multicolumn{7}{|c|}{ Iskolai végzettség } \\
\hline alapfokú & 10,5 & 438 & 41523 & 11,1 & 270 & 24171 \\
\hline szakmunkás & 9,6 & 495 & 51335 & 11,8 & 325 & 27442 \\
\hline középfokú & 8,3 & 714 & 85369 & 8,4 & 429 & 50742 \\
\hline felsőfokú & 10,2 & 390 & 38026 & 12,5 & 285 & 22682 \\
\hline \multicolumn{7}{|l|}{$\begin{array}{c}\text { Partner iskolai } \\
\text { végzettsége }\end{array}$} \\
\hline alapfokú & 13,9 & 120 & 8573 & 12,9 & 115 & 88951 \\
\hline szakmunkás & 10,4 & 658 & 62738 & 9,6 & 579 & 60100 \\
\hline középfokú & 9,9 & 411 & 41192 & 9,6 & 365 & 37687 \\
\hline felsőfokú & 15,6 & 300 & 19171 & 13,4 & 261 & 19351 \\
\hline \multicolumn{7}{|l|}{ Tanul } \\
\hline nem tanul & 9,3 & 1950 & 207488 & 10,4 & 1260 & 120241 \\
\hline tanul & 10,1 & 109 & 10733 & 10,4 & 60 & 5748 \\
\hline \multicolumn{7}{|l|}{ életkor } \\
\hline $15-19$ & 16,2 & 149 & 9165 & 16,9 & 74 & 4379 \\
\hline $20-24$ & 16,6 & 849 & 50909 & 18,6 & 521 & 27898 \\
\hline $25-29$ & 14,0 & 791 & 56185 & 16,0 & 535 & 33333 \\
\hline $30-34$ & 5,8 & 231 & 39491 & 7,0 & 169 & 23871 \\
\hline $35-49$ & 0,6 & 39 & 62528 & 0,5 & 20 & 36551 \\
\hline \multicolumn{7}{|c|}{ Születési kohorsz } \\
\hline 1951-1955 & 11,7 & 559 & 47552 & 8,9 & 224 & 24981 \\
\hline 1956-1960 & 9,9 & 1093 & 110230 & 9,1 & 278 & 30349 \\
\hline 1961-1965 & 7,7 & 360 & 46451 & 9,2 & 229 & 24696 \\
\hline $1966-1970$ & 3,3 & 47 & 14045 & 13,0 & 258 & 19756 \\
\hline 1971-1975 & & & & 12,7 & 203 & 15950 \\
\hline 1976-1980 & 7,3 & 114 & 15481 & 12,3 & 127 & 10301 \\
\hline
\end{tabular}

Megjegyzés: súlyozott becslések az Életünk fordulópontjai felvétel adataiból kialakított eseménytörténeti adatbázison.

A második gyermekvállalás esélye és az iskolai végzettség közötti összefüggés tehát U alakú. Árnyalja a képet, ha az események és a hónapok számát is szemügyre vesszük. Az érettségizettek körében valamivel kevesebb mint kétszer annyi szülés 
történt, mint a diplomások körében. Az 1. táblázatban láttuk, hogy a mintában durván kétszer annyi érettségizett nő van, mint ahány diplomás. A hazárdrátákban mutatkozó különbség oka tehát nem az, hogy a két csoport között eltér a megfigyelt események száma, hanem az, hogy az érettségizettek körében több mint kétszer akkora a várakozási idők összege, mint a diplomások körében.

\section{MODELLSPECIFIKÁCIÓ ÉS BECSLÉSI MÓDSZEREK}

A regresszióelemzésben az iskolai végzettség kategóriák a fő magyarázó változók. A kontrollváltozók az életkor, a születési kohorsz és hogy tanul-e éppen az egyén. A nemzetközi kutatások többségében életkor- és kohorsz-kategóriákat használnak. Elemzésünk eltér ettől a gyakorlattól: a születési évet és annak négyzetét, illetve az életkor logaritmusát és az életkort használjuk a kohorsz és az életkor hatásának megragadására. A születési év változókkal azt feltételezzük, hogy a gyermekvállalási kedv a születési év nem állandó ütemben csökkenő (vagy növekvő) függvénye. A 2. ábra azt sugallja, hogy a második gyermekvállalás valószínüsége a születési év fordított $U$ alakú függvénye. Ezt az összefüggést ragadhatjuk meg, ha a regressziós modellben a születési év mellett annak négyzete is szerepel. Hogy a két változó korrelációja minél kisebb legyen, a születési évből kivonunk 1960-at, majd ezt a változót emeljük négyzetre.

Az életkor változók specifikálása bővebb kifejtést érdemel. Közismert, hogy a szülések - megfigyelt vagy regressziókból becsült - gyakorisága az életkor először növekvő, majd csökkenő függvénye. Ez a - gyakran fordított U alakúnak nevezett - minta levezethető abból a feltevésből, hogy az életkorkomponens két elemi valószínüség szorzata. Az első valószínűség arra az eseményre vonatkozik, hogy az egyén biztosította a gyermekvállaláshoz, gyermekneveléshez szükséges javakat. Ez a valószínüség az életkor növekvő függvénye. A második valószínűség arra az eseményre vonatkozik, hogy a szülés kockázatmentes és a gyermek egészséges lesz. Ez a valószínűség az életkor csökkenő függvénye, hiszen a szóban forgó kockázatok az idősebb nőkre vonatkoznak. E két megfontolás alapján a hazárdráta életkorfüggését az alábbi függvénnyel definiálhatjuk:

$$
h_{a}=a^{\beta}(T-a)^{\gamma}
$$

a az életkor, T a termékeny évek (vagy hónapok) száma. $\beta$ és $\gamma$ paraméterek. A képlet valójában a béta eloszlás sűrűségfüggvénye. Mivel a hazárdráta-modellekben a hazárdráta logaritmusát modellezzük, a fenti függvény logaritmusa:

$$
\log h=\beta \log a+\gamma \log (T-a)
$$


A $\beta$ paraméter fejezi ki, hogyan nő a gyermekvállalás valószínűsége az életkor előrehaladásával. Ha a paraméter értéke közel van a nullához, a gyermekvállalási szándékok már fiatalkorban nagyon erősek, és ezután már csak kismértékben nőnek. Ha viszont a paraméter egynél nagyobb, a gyermekvállalási szándékok csak idősebb korban válnak számottevővé. A gyermekvállaláshoz szükséges erőforrások biztosításának könnyedsége vagy nehézsége tehát kifejezhető a $\beta$ paraméterrel. A $\gamma$ paraméter azt fejezi ki, mennyire reagál érzékenyen a gyermekvállalási intenzitás arra, hogy az aktuális életkor egyre közelebb kerül a gyermekvállalási életkor végéhez.

Az (1) egyenleten alapuló modellspecifikáció megtalálható Blossfeld és Huinink (1991) klasszikus munkájában. A specifikációt később Kalmijn és Gelissen (2007) használta. A specifikációnak egy apróbb hátránya van: a regressziós modell konstansa nehezen értelmezhető, mivel a és ( $T$-a) nem lehetnek egyszerre nullák (ha az egyik nulla, a másik szükségszerüen zérustól eltérő szám). A konstans értelmezhetőségének érdekében a második komponenst magával az életkorral közelítjük. Az életkorfüggést tehát a

$$
\log h=\beta \log a+\gamma a
$$

függvénnyel modellezzük. Az elemzés során használt logaritmus életkor változó valójában (életkor-14) természetes alapú logaritmusa, a lineáris életkor változó pedig (életkor-15). Ezek a transzformációk garantálják, hogy a konstans a termékeny életkor kezdetére vonatkozó hazárdrátát fejezze ki.

\section{3. táblázat: Az elemzések során használt modellspecifikációk}

Model specifications used during data analyses

\begin{tabular}{|c|c|c|c|c|}
\hline Változók & 1. modell & 2. modell & 3. modell & 4. modell \\
\hline Iskolai végzettséget mérő változókª & $x$ & $x$ & $x$ & $x$ \\
\hline Iskolai részvétel & $x$ & $x$ & $x$ & $x$ \\
\hline $\begin{array}{l}\text { Életkor változók: } \\
\text { log(életkor-14), (életkor-15) }\end{array}$ & $x$ & $x$ & $x$ & $x$ \\
\hline $\begin{array}{l}\text { Kohorsz változók: } \\
\text { (születési év - 1960) és annak négyzete }\end{array}$ & $x$ & $x$ & $x$ & $x$ \\
\hline \multicolumn{5}{|l|}{ Szorzatváltozók: } \\
\hline Iskolai végzettség X életkor változók & & $x$ & & $x$ \\
\hline Iskolai végzettség X kohorsz változók & & & $x$ & $x$ \\
\hline
\end{tabular}

Megjegyzés: a A partnerhatás-hipotézis tesztelésénél a partner iskolai végzettségét mérő változókat is tartalmazza. 
Az elemzés során négy modellt használunk. Felépítésüket a 3. táblázat szemlélteti. Az 1. modell a legegyszerübb: az iskolai végzettséget, az iskolai részvételt, valamint az életkor és a kohorsz változókat tartalmazza. A 2. modell az iskolai végzettség és az életkor változók interakcióival bővíti ki az első modellt. A szorzatváltozókkal tudjuk modellezni, hogy eltérő iskolai végzettségű nők körében eltérő a második gyermekvállalás optimális életkora és a gyermekvállalás-életkorprofil formája. A 2. modellt az időprés-hipotézis tesztelésére fogjuk használni. A 3. modell is az elsőre épül, és az iskolai végzettség és a születési év változók közti interakciók jelentik az új változókat. Ezekkel a szorzatváltozókkal azt a hipotézist tudjuk ellenőrizni, hogy az iskolai végzettség szerinti különbségek kohorszról kohorszra eltérhetnek. Végül a 4. modell a 2. és a 3. modellbe bevont szorzatváltozókat egyszerre tartalmazza.

Mindegyik modellt kétféle módszerrel becsüljük. Az első módszer a második gyermekvállalást magyarázó modell szokásos (független) becslése logisztikus regresszióval. A második módszer a szimultán eseménytörténeti elemzés logikáját követi. A második gyermekvállalást magyarázó logisztikus regressziós modellt együtt becsüljük az első gyermekvállalást magyarázó diszkrét eseménytörténeti (logisztikus regressziós) modellel. Ez a szimultán becslés, amely azt feltételezi, hogy az első és a második gyermekvállalást magyarázó modellek egymással korreláló véletlen egyedhatásokat tartalmaznak. Mivel a véletlen egyedhatások mindkét gyermekvállalásnál ugyanabba az irányba hatnak, a korreláció modellezhető egy közös egyénszintű hibataggal. A szimultán modell tehát a többszintű regressziós modellek speciális esete.

A becslések során súlyokat használunk. A súlyok az Életünk fordulópontjai felvételhez készített kalibrált súlyokon alapulnak (Bartus 2015). Az 1946-1970 között született nőknél a súlyt újrakalibráltuk úgy, hogy a minta iskolázottság, születési kohorsz kategóriák (1946-1950, 1951-1955, 1956-1960, 1961-1965, 1966-1970) és gyermekszám szerinti eloszlása megfeleljen a 2011-es népszámlálás eloszlásának.

\section{EREDMÉNYEK}

\section{Iskolai végzettség és második gyermekvállalás}

Először arra keressük a választ, milyen hatása van a női iskolai végzettségnek a második gyermekvállalásra. Az 1. modell becslési eredményeit a 4. táblázat tartalmazza. Vegyük szemügyre először a független becsléseket! Hipotézisünk 
szerint az iskolai végzettség és a második gyermekvállalás összefüggése $U$ alakú. Mivel az érettségizett végzettséget vesszük referenciakategóriának, azt várjuk, hogy az alapfokú, a szakmunkás és a diploma változók együtthatói mind pozitívak. Az alapfokú iskolai végzettség változó együtthatója pozitív $(b=0,165)$ és statisztikailag szignifikáns ( $p=0,021)$. Az érettségizett nőkhöz viszonyítva a második gyermek vállalásának esélye tehát magas a legfeljebb 8 általánossal rendelkező nők körében. A szakmunkás végzettség változó együtthatója ugyan pozitív ( $b=0,005)$, de statisztikailag nem szignifikáns $(p=0,944)$. Végül a felsőfokú végzettség változó együtthatója pozitív $(b=0,405)$ és statisztikailag szignifikáns ( $p=0,000)$. Az második gyermek vállalásának esélye tehát a diplomás nők körében magasabb, mint az érettségizettek körében. Az iskolai végzettség változók együtthatói együttesen szignifikánsak még az 1 ezrelékes szinten is. Az eredmények tehát megerősítik az U alakú összefüggésre vonatkozó hipotézist.

Vegyük szemügyre ezután a gyermekvállalási esély élekorfüggését is! Ha a gyermekvállalási kedv először nő, majd csökken az életkor előrehaladásával, akkor a log (életkor-14) változó együtthatójának pozitívnak, a lineáris élektor változó együtthatójának pedig negatívnak kell lennie. Az előbbi változó együtthatója pozitív ( $b=2,600)$ és statisztikailag szignifikáns ( $p=0,000)$; az utóbbié negatív $(b=-0,352)$ és statisztikailag szignifikáns $(p=0,000)$. Az eredmények tehát egybecsengenek a várakozásokkal.

4. táblázat: A második gyermekvállalást magyarázó 1. modell becslései Parameter estimates of Model 1 predicting second births

\begin{tabular}{llccc} 
& \multicolumn{2}{c}{ Független becslés } & \multicolumn{2}{c}{ Szimultán becslés } \\
\hline Iskolai végzettség: alapfokú & $0,1651^{*}$ & $(2,309)$ & $0,5119^{* * *}$ & $(5,197)$ \\
Iskolai végzettség: szakmunkás & 0,0050 & $(0,070)$ & $0,1775^{*}$ & $(2,010)$ \\
Iskolai végzettség: középfokú & 0 & & 0 & \\
Iskolai végzettség: felsőfokú & $0,4054^{* * *}$ & $(5,187)$ & $0,3357^{* * *}$ & $(3,834)$ \\
log (életkor-14) & $2,6002^{* * *}$ & $(8,222)$ & $4,7358^{* * *}$ & $(10,248)$ \\
életkor-15 & $-0,3516^{* * *}$ & $(13,490)$ & $-0,4382^{* * *}$ & $(13,005)$ \\
Tanul & $-0,1564$ & $(1,407)$ & $-0,2283$ & $(1,916)$ \\
születési év - 1960 & $-0,0008$ & $(0,272)$ & $-0,0043$ & $(1,120)$ \\
(születési év - 1960) négyzete & 0,0000 & $(0,167)$ & $-0,0015^{* *}$ & $(3,089)$ \\
Konstans & $-6,9958^{* * *}$ & $(14,330)$ & $-11,2575^{* * *}$ & $(14,660)$
\end{tabular}

Megjegyzés: A zárójelben szereplő számok a Hubert/Whyte standard hiba becsléseken nyugvó $t$ statisztikák. * $p<0,05 ;{ }^{* *} p<0,01 ;{ }^{* * *} p<0,001$. A megfigyelések (személy-periódusok) súlyozatlan száma a második gyermekvállalást magyarázó modellekben: 86 552. Az egyének száma: 3354. Az egyénszintű véletlenhatás varianciája a szimultán modellben: 1,017. 
Végül azt várjuk, hogy a második gyermekvállalás a születési kohorsz fordított $U$ alakú függvénye. A születési év változó együtthatója ugyan negatív, de nem szignifikáns. A négyzetes változó sem szignifikáns, az együttható nullához közeli. Nincs tehát bizonyítékunk arra, hogy a születési év befolyásolná a második gyermekvállalás esélyét.

A független becslés eredményei azonban torzítottak lehetnek, hiszen az egygyermekes anyák mintája nem tekinthető a nők véletlen mintájának, és az anyák iskolázottság, életkor és kohorsz szerint homogén mintája heterogén lehet a gyermekvállalási kedvet befolyásoló, nem megfigyelt személyiségjegyek szerint. Az ebből fakadó esetleges torzításokat minimalizálja a szimultán becslési módszer. A szimultán becslés eredményei alapvetően egybecsengenek a független becslés eredményeivel. A legfontosabb egyezés, hogy a felsőfokú végzettség változó együtthatója ismét pozitív $(b=0,336)$ és statisztikailag szignifikáns ( $p=0,000)$. Mivel az alapfokú végzettség változó együtthatója is pozitív és szignifikáns, ismét arra következtethetünk, hogy a második gyermekvállalás az iskolai végzettség U alakú függvénye.

A szimultán becslés hozzáadott értéke, hogy cáfolni tudjuk azt a hipotézist, miszerint az iskolázottság és a második gyermekvállalás összefüggése a minta szelektív összetételéből fakad. Emelett érdemes megjegyezni, hogy a szimultán becsléssel a születési év változó négyzetének együtthatója negatív és szignifikáns lesz. Ez azt jelenti, hogy a második gyermekvállalás esélye a születési év fordított $U$ alakú függvénye. A lineáris komponens együtthatójának és a négyzetes tag együtthatójának hányadosa közel van -3-hoz. A második gyermekvállalást „maximalizáló” születési év ennek az értéknek a mínusz 0,5-szöröse, tehát durván 1,5. Mivel a születési év változó a tényleges születési év és 1960 különbsége, a második gyermekvállalási valószínűség ceteris paribus az 1961-1962-ben született nők körében a legmagasabb.

\section{Az időprés-hipotézis}

Magyarázható-e az iskolázottság és a második gyermekvállalás összefüggése az első szülés késői életkorra halasztásával? A kérdést a 2. modell becslésével vizsgáljuk. Ebben a modellben szerepelnek az iskolai végzettség és az életkor változók interakciói is. Az időprés-hipotézis alapján azt várjuk, hogy a diplomások körében - a többi iskolai végzettséghez viszonyítva - lassan nő, majd az optimális gyermekvállalási életkor elérése után lassan csökken a gyermekvállalás valószínűsége. Az életkor szerinti növekedés ütemét a logaritmus életkor változó együtthatója fejezi ki: minél nagyobb ez az együttható, annál lassabb a 
növekedési ütem. Az iskolai végzettség emelkedésével tehát nőnie kell a logaritmus életkor változó együtthatójának. Másképp fogalmazva: a felsőfokú végzettség és a logaritmus életkor változók szorzatának pozitív lesz az együtthatója. Mivel az érettségi a referenciakategória, azt kell tapasztalnunk, hogy egyrészt az alapokú és a szakmunkás változók, másrészt a logaritmus életkor változó közötti interakciós változók együtthatója negatív.

5. táblázat: A második gyermekvállalást magyarázó 2. modell becslései Parameter estimates of Model 2 predicting second births

\begin{tabular}{|c|c|c|c|c|}
\hline \multirow[b]{2}{*}{ Iskolai végzettség: alapfokú } & \multicolumn{2}{|c|}{ Független becslés } & \multicolumn{2}{|c|}{ Szimultán becslés } \\
\hline & $6,3736^{* * *}$ & $(5,345)$ & $6,6366^{* * *}$ & $(4,877)$ \\
\hline Iskolai végzettség: szakmunkás & $3,1264^{*}$ & $(2,399)$ & 2,3418 & $(1,607)$ \\
\hline Iskolai végzettség: középfokú & 0 & & 0 & \\
\hline Iskolai végzettség: felsőfokú & $-8,0675^{* *}$ & $(3,179)$ & $-8,9877^{* *}$ & $(3,233)$ \\
\hline log (életkor-14) & $5,4117^{* * *}$ & $(8,157)$ & $7,1803^{* * *}$ & $(10,065)$ \\
\hline életkor-15 & $-0,5598^{* * *}$ & $(10,366)$ & $-0,6159^{* * *}$ & $(11,175)$ \\
\hline Tanul & $-0,1897$ & $(1,705)$ & $-0,2991^{*}$ & $(2,509)$ \\
\hline születési év - 1960 & $-0,0019$ & $(0,625)$ & $-0,0063$ & $(1,637)$ \\
\hline (születési év - 1960) négyzete & 0,0000 & $(0,113)$ & $-0,0016^{* * *}$ & $(3,292)$ \\
\hline $\begin{array}{l}\text { Iskolai végzettség: alapfokú X } \\
\text { log (életkor-14) }\end{array}$ & $-3,8594^{* * *}$ & $(4,882)$ & $-3,7631^{* * *}$ & $(4,226)$ \\
\hline $\begin{array}{l}\text { Iskolai végzettség: szakmunkás } \\
\text { X log (életkor-14) }\end{array}$ & $-1,7761^{*}$ & $(2,081)$ & $-1,1577$ & $(1,229)$ \\
\hline $\begin{array}{l}\text { Iskolai végzettség: felsőfokú X } \\
\text { log (életkor-14) }\end{array}$ & $4,5614^{* *}$ & $(3,050)$ & $4,9119^{* *}$ & $(3,047)$ \\
\hline $\begin{array}{l}\text { Iskolai végzettség: alapfokú X } \\
\text { életkor }\end{array}$ & $0,2753^{* * *}$ & $(4,016)$ & $0,2579^{* * *}$ & $(3,441)$ \\
\hline $\begin{array}{l}\text { Iskolai végzettség: szakmunkás } \\
\text { X életkor }\end{array}$ & 0,1080 & $(1,474)$ & 0,0620 & $(0,787)$ \\
\hline $\begin{array}{l}\text { Iskolai végzettség: felsőfokú X } \\
\text { életkor }\end{array}$ & $-0,2634^{*}$ & $(2,453)$ & $-0,2703^{*}$ & $(2,405)$ \\
\hline Konstans & $-11,5229^{* * *}$ & $(11,076)$ & $-15,2255^{* * *}$ & $(13,145)$ \\
\hline
\end{tabular}

Megjegyzés: A zárójelben szereplő számok a Hubert/Whyte standard hiba becsléseken nyugvó t statisztikák. * $p<0,05$; ${ }^{* *} p<0,01 ;{ }^{* * *} p<0,001$. A megfigyelések (személy-periódusok) súlyozatlan száma a második gyermekvállalást magyarázó modellekben: 86 552. Az egyének száma: 3354. Az egyénszintű véletlenhatás varianciája a szimultán modellben: 0,987.

Az életkor szerinti csökkenés ütemét a lineáris életkor változó együtthatója adja vissza: a gyermekvállalási szándékok csökkenése annál komolyabb, minél kisebb - a nullától minél távolabbi negatív szám - a lináris életkor változó 
együtthatója. Az a várakozás, hogy a diplomások között még a késői életkorban is nagy a második gyermekvállalás intenzitása, azt vonja maga után, hogy a felsőfokú végzettség és a lineáris életkor változó interakciós hatása negatív. A referenciakategória megválasztása miatt az alapokú és a szakmunkás változóknak a lineáris életkor változóval képzett interakciós hatásainak pozitívnak kell lenniük.

A várakozásokat alátámasztják az 5. táblázatban látható eredmények. Akár a független, akár a szimultán becsléseket vesszük, az iskolázottság és az életkor változók közötti interakciós hatások többsége szignifikáns. A becslési módszernek nincs hatása a tartalmi következtetésekre, ami azt sugallja, hogy az esetleges nem megfigyelt személyiségjegyek nem befolyásolják lényegesen a gyermekvállalást. A szorzatváltozók együtthatói azt sugallják, hogy a logaritmus életkor hatása az alacsony iskolai végzettségü nők körében viszonylag alacsony, a diplomás nők körében viszont magas. Ezzel ellentétesen változik a lineáris életkor változó hatása.

Az iskolai végzettség szerinti gyermekvállalási életkorprofilokat a 3. ábra mutatja. A függőleges tengelyre a becsült hazárdrátákat (azaz a második szülések havi intenzitását), a vízszintes tengelyre az életkort mértük fel. Az iskolázottságspecifikus becslések a 2. modell független becsléseiből származnak. Az ábra készítésekor azt feltételeztük, hogy a nők 1970-ben születtek és nem járnak iskolába.

Az ábra világosan mutatja a gyermekvállalási életkorprofilok iskolai végzettség szerinti eltéréseit. A második gyermekvállalás optimális életkora - vagyis az az életkor, amelynél a gyermekvállalás intenzitása maximális - az iskolai végzettség növekvő függvénye. Ez az optimális életkor alapfokú végzettségű nők körében 19,5, szakmunkás végzettségü nők körében 22, érettségizett nők körében 23,7, diplomás nők körében 26,1 év. Érdemes megjegyezni, hogy az optimális életkorokban mutatkozó különbségek kisebbek, mint amit az alapján várnánk, hogy az eltérő iskolai végzettségü egyének eltérő időt töltenek el az iskolapadban. A diplomások és a legfeljebb 8 általánost végzett nők közti különbség például 6,7 év - ezzel szemben az iskolában eltöltött évek különbsége legalább 7 év (4 év középiskola és 3 év főiskola). Érdemes azt is megjegyezni, hogy a 24 évesnél idősebb nők körében a diplomások azok, akik a legnagyobb eséllyel vállalnak második gyermeket.

Első látásra ez a minta alátámasztja az időprés-hipotézist. A hipotézis teszteléséhez azonban azt is meg kell vizsgálni, hogy tényleg beszükíti-e a második gyermekvállalásra maradó időt az első gyermekvállalás kitolódása. Az „időprés” iskolázottságspecifikus mértékét az első gyermekvállalás átlagos életkorának és a második gyermekvállalás optimális életkorának összehasonlításával itélhetjük 
3. ábra: A második gyermekvállalás becsült havi valószínüsége az iskolai végzettség és az életkor függvényében

Estimated monthly second birth intensities by level of education and age

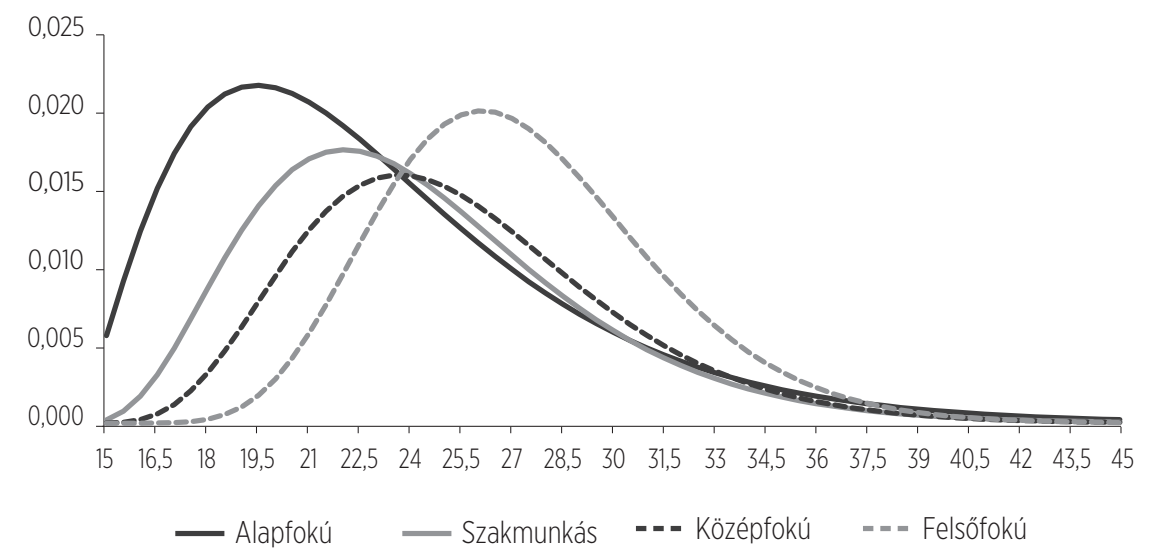

Megjegyzés: A 2. modellspecifikáció független becsléséből számolt eredmények. Az ábra készítése során rögzített változók: születési év = 1970, a tanul változó értéke = 0. A második gyermekvállalás optimális élekora alapfokú végzettségü nők körében 19,5, szakmunkás végzettségü nők körében 22, érettségizett nők körében 23,7, diplomás nők körében 26,1 év. Az első gyermekvállalás átlagos életkora alapfokú végzettségű nők körében 21,2, szakmunkás végzettségű nők körében 21,5, érettségizett nők körében 23,4, diplomás nők körében 25,4 év.

meg. A második gyermekvállalás optimális életkora alapfokú végzettségű nők körében 19,5, szakmunkás végzettségü nők körében 22, érettségizett nők körében 23,7, diplomás nők körében 26,1 év. Az első gyermekvállalás átlagos életkora alapfokú végzettségü nők körében 21,2, szakmunkás végzettségü nők körében 21,5, érettségizett nők körében 23,4, diplomás nők körében 25,4 év. Az első gyermekvállalás átlagos életkorának és a második gyermekvállalás optimális életkorában összehasonlítása rendkívül vegyes eredményekre vezet. Az átlagos diplomás nőnek alig egy éve marad arra, hogy optimálisan időzítse a második gyermekvállalást. De ugyanilyen - pontosabban ennél valamivel komolyabb nyomásnak vannak kitéve a szakmunkás és középfokú végzettséggel rendelkező nők is: náluk az átlag és az optimum különbsége csupán fél év. Az „időprés” viszonylag azonos hossza ellenére e három csoportban eltér a második szülések intenzitása. Ráadásul az iskolázatlan nők körében az optimum kisebb az átlagnál - a „negatív időprés” ellenére ők mégis nagy valószínűséggel vállalnak második gyermeket. Az eredmények alapján tehát úgy tünik, hogy az időprés-hipotézis nem adhat magyarázatot arra, miért magas a diplomás nők körében a második szülések intenzitása. 
Az időprés-hipotézist úgy is ellenőrizhetjük, ha az életkor változókat kicseréljük az első szülés időpontjában mért életkor változóval. Mivel az életkor az első szüléskori életkor és az első gyermek életkorának az összege, az életkorfüggés modellezéséhez elvileg a

$$
\log h=\beta \log (b+c)+\gamma(b+c)
$$

egyenletet kellene használni, ahol b az első szüléskori életkor, c pedig az első gyermek életkora. Ez az egyenlet egy olyan specifikációt sugall, ahol a két lineáris életkor változó (életkor az első szüléskor, illetve az első gyermek életkora) mellett azok logaritmusa is szerepel.

Az első szülési életkor és a gyermek életkorát (valamint azok logaritmusait) tartalmazó 2. modell becsléseit nem közöljük. A diploma változó együtthatója -31, a diploma log életkor első szülésé 13 volt. Az ilyen nagy logisztikus regreszsziós együthatók nem a hatás nagyságával magyarázhatók, hanem azzal, hogy a magyarázó változók által definiált többdimenziós táblázatban vannak olyan cellák, ahol szinte mindenkinek (vagy szinte senkinek sem) született gyermeke. Az efféle adatproblémák jelentősen veszélyeztetik a maximum likelihood becslési eljárás megbízhatóságát. Annak érdekében, hogy a becslések megbízhatóak legyenek, a logaritmus változók nélkül végeztem el a becslést. Az iskolai végzettség változók és az első szülés életkor változó interakciói nem voltak statisztikailag szignifikánsak. Ennek fényében tehát nincs bizonyítékunk arra, hogy az első szülések elhalasztása eltérő hatást gyakorolna a különböző iskolai végzettségü csoportok között.

Az eredmények tehát azt sugallják, hogy a női iskolázottság második gyermekvállalásra gyakorolt hatása nem magyarázható meggyőzően sem a szelekciós torzítás fogalmával, sem az időprés-hipotézissel. A következtetést megerősíti a 3. és a 4. modellek becslése is. Az iskolai végzettség és a születési év változók közti interakciós hatások együtthatói nem voltak szignifikánsak sem a független, sem a szimultán modellben. Úgy tűnik tehát, hogy az iskolai végzettség valódi oksági hatást gyakorol a második gyermekvállalás intenzitására, ami az érettségizettek körében alacsonyabb, mint a diplomás nők között.

\section{A partnerhatás-hipotézis}

Magyarázható-e az iskolai végzettség és a második gyermekvállalás kapcsolata azzal, hogy a nők élet- vagy házastársai hasonló iskolai végzettséggel rendelkeznek, és a partner iskolai végzettsége növeli a második gyermekvállalás 
esélyét? A kérdés megválaszolásához a partner iskolai végzettségét is bevonjuk az elemzésbe. Az elemzés azokra a nőkre korlátozódik, akiknek volt partnerük az első gyermek születésekor. Ismét a 3. táblázatban bemutatott modelleket becsüljük. Az 1. modell a legegyszerűbb: a partner és a nő iskolai végzettségét, az iskolai részvételt, valamint az életkor és a kohorsz változókat tartalmazza. A 2. modell az iskolai végzettség és az életkor változók interakcióival bővíti ki az első modellt. A 3. modell is az elsőre épül, és az iskolai végzettség és a születési év változók közti interakciók jelentik az új változókat. Végül a 4. modell a 2. és a 3. modellbe bevont szorzatváltozókat egyszerre tartalmazza.

6. táblázat: A partner iskolai végzettségével kibővitett 1. modell becslései Parameter estimates of Model 1 augmented with partner's education

\begin{tabular}{lllll} 
& \multicolumn{2}{c}{ Független becslés } & \multicolumn{2}{c}{ Szimultán becslés } \\
\hline $\begin{array}{l}\text { Partner iskolai végzettsége: } \\
\text { alapfokú }\end{array}$ & 0,0868 & $(0,540)$ & 0,2259 & $(1,378)$ \\
$\begin{array}{l}\text { Partner iskolai végzettsége: } \\
\text { szakmunkás }\end{array}$ & $-0,1395$ & $(1,785)$ & $-0,0534$ & $(0,660)$ \\
$\begin{array}{l}\text { Partner iskolai végzettsége: } \\
\text { középfokú }\end{array}$ & 0 & & 0 & \\
Partner iskolai végzettsége: & & & & \\
felsőfokú & $0,3797^{* * *}$ & $(4,172)$ & $0,3765^{* * *}$ & $(3,865)$ \\
Iskolai végzettség: alapfokú & $0,2303^{*}$ & $(2,040)$ & $0,3989^{* * *}$ & $(3,394)$ \\
Iskolai végzettség: szakmunkás & $0,1754^{*}$ & $(2,017)$ & $0,2347^{* *}$ & $(2,642)$ \\
Iskolai végzettség: középfokú & 0 & & 0 & \\
Iskolai végzettség: felsőfokú & $0,3653^{* * *}$ & $(4,042)$ & $0,3305^{* * *}$ & $(3,533)$ \\
Iog (életkor-14) & $3,1292^{* * *}$ & $(9,342)$ & $3,7987^{* * *}$ & $(9,378)$ \\
életkor & $-0,3911^{* * *}$ & $(14,108)$ & $-0,4139^{* * *}$ & $(12,819)$ \\
Tanul & $-0,1965$ & $(1,458)$ & $-0,2030$ & $(1,421)$ \\
születési év - 1960 & 0,0028 & $(0,386)$ & 0,0081 & $(1,088)$ \\
(születési év - 1960) négyzete & $-0,0007$ & $(1,291)$ & $-0,0018^{* *}$ & $(3,118)$ \\
Konstans & $-7,6607^{* * *}$ & $(14,660)$ & $-9,0499^{* * *}$ & $(13,975)$ \\
Iskolai végzettség: felsőfokú X & $-0,2634^{*}$ & $(2,453)$ & $-0,2703^{*}$ & $(2,405)$ \\
életkor & $-11,5229^{* * *}$ & $(11,076)$ & $-15,2255^{* * *}$ & $(13,145)$ \\
Konstans & & & &
\end{tabular}

Megjegyzés: A zárójelben szereplő számok a Hubert/Whyte standard hiba becsléseken nyugvó $t$ statisztikák. ${ }^{*} p<0,05 ;{ }^{* *} p<0,01 ;{ }^{* * *} p<0,001$. A megfigyelések (személy-periódusok) súlyozatlan száma a második gyermekvállalást magyarázó modellekben: 45 417. Az egyének száma: 2256. Az egyénszintű véletlenhatás varianciája a szimultán modellben: 0,415. 
Az 1. modell becslési eredményeit a 6. táblázat tartalmazza. A független és a szimultán becslések eredményei hasonlóak. A partner iskolai végzettségét megragadó változók közül csak a diplomát mérő változó együtthatója szignifikáns. Az együttható pozitív, ami azt jelenti, hogy az érettségizett partnerekkel rendelkező nőkhöz képest a diplomás partnerrel rendelkező nők nagyobb eséllyel vállalnak második gyermeket. A nő iskolai végzettségét mérő változók együtthatói pozitívak és statisztikailag szignifikánsak. A második gyermekvállalás és a női iskolai végzettség között tehát U alakú összefüggés van.

Az interakciókat is tartalmazó 2-4. modellek becslési eredményeit nem közöljük, mert az együtthatók és a szignfikanciák nagyon hasonlóak az 1. modell becsléseihez. A 2-4. modelleknél is azt tapasztaljuk, hogy a partner iskolázottságát megragadó változók együtthatói közül csak a diplomás partneré szignifikáns. A szóban forgó együttható mindig pozitív. Ez az eredmény megerősíti az 1. modellből levont következtetést, miszerint a diplomás partnerrel rendelkező nők körében a legmagasabb a második gyermekvállalás esélye.

Mivel az érettségihez képest mind a nő, mind a férfi iskolai végzettsége növeli a gyermekvállalás esélyét, a diplomás pároknak kiugróan magas eséllyel kell második gyermeket vállalniuk. Hogy ezt a hipotézist ellenőrizzük, a női és férfi iskolai végzettség változókból kialakítottunk egy 10 kategóriát tartalmazó összevont változót, ami leírja a pár iskolai végzettségét. Ezután újrabecsültük a modelleket úgy, hogy a nő és a férfi iskolai végzettsége helyett ezt az öszevont változót használtuk. Az 1. modell eredményeit a 7. táblázat tartalmazza. A független becslés eredményei szerint az érettségizett párokhoz képest a diplomás párok szignifikánsan magasabb, a lefele házasodó nők pedig szignifikánsan alacsonyabb eséllyel vállalnak második gyermeket. A szimultán becslésnél megmarad a diplomás párok pozitív és szignifikáns együtthatója, a lefele házasodó érettségizett nőket azonosító változó együtthatója viszont már nem szignifikáns az 5\%-os szinten. Ehelyett az iskolázatlan párokat és a lefele házasodó szakmunkás nőket azonosító változók szignifikánsak. Habár az eredmények vegyesek, mindkét becslés megerősíti azt a sejtést, hogy a diplomás párok nagy eséllyel vállalnak második gyermeket. Ha a szimultán becsléseknek hiszünk, ismét $U$ alakú összefüggést találunk iskolázottság és gyermekvállalás között: legnagyobb eséllyel a legfeljebb 8 általános iskolát végzett nők, valamint a diplomás párok vállalnak második gyermeket. 
7. táblázat: A pár iskolai végzettsége és a második gyermekvállalás

Effect of couple's education on second births

\begin{tabular}{|c|c|c|c|c|}
\hline \multirow[b]{2}{*}{$\begin{array}{l}\text { Pár iskolai végzettsége: } \\
\text { alapfokú - parneré ugyanaz }\end{array}$} & \multicolumn{2}{|c|}{ Független becslés } & \multicolumn{2}{|c|}{ Szimultán becslés } \\
\hline & 0,2402 & $(1,120)$ & $0,5840^{* *}$ & $(2,615)$ \\
\hline $\begin{array}{l}\text { Pár iskolai végzettsége: } \\
\text { alapfokú - parneré magasabb }\end{array}$ & 0,0285 & $(0,223)$ & 0,2388 & $(1,774)$ \\
\hline $\begin{array}{l}\text { Pár iskolai végzettsége: } \\
\text { szakmunkás - parneré } \\
\text { alacsonyabb }\end{array}$ & 0,3491 & $(1,925)$ & $0,4538^{*}$ & $(2,303)$ \\
\hline $\begin{array}{l}\text { Pár iskolai végzettsége: } \\
\text { szakmunkás - parneré } \\
\text { ugyanaz }\end{array}$ & $-0,0820$ & $(0,719)$ & 0,0596 & $(0,508)$ \\
\hline $\begin{array}{l}\text { Pár iskolai végzettsége: } \\
\text { szakmunkás - parneré } \\
\text { magasabb }\end{array}$ & 0,1040 & $(0,822)$ & 0,1589 & $(1,143)$ \\
\hline $\begin{array}{l}\text { Pár iskolai végzettsége: } \\
\text { középfokú - parneré } \\
\text { alacsonyabb }\end{array}$ & $-0,2920^{*}$ & $(2,539)$ & $-0,2250$ & $(1,935)$ \\
\hline $\begin{array}{l}\text { Pár iskolai végzettsége: } \\
\text { középfokú - parneré ugyanaz }\end{array}$ & 0 & & 0 & \\
\hline $\begin{array}{l}\text { Pár iskolai végzettsége: } \\
\text { középfokú - parneré } \\
\text { magasabb }\end{array}$ & 0,2181 & $(1,536)$ & 0,1832 & $(1,120)$ \\
\hline $\begin{array}{l}\text { Pár iskolai végzettsége: } \\
\text { felsőfokú - parneré } \\
\text { alacsonyabb }\end{array}$ & 0,1902 & $(1,530)$ & 0,1343 & $(1,064)$ \\
\hline $\begin{array}{l}\text { Pár iskolai végzettsége: } \\
\text { felsőfokú - parneré ugyanaz }\end{array}$ & $0,6710^{* * *}$ & $(6,225)$ & $0,6469^{* * *}$ & $(5,984)$ \\
\hline log (életkor-14) & $3,1124^{* * *}$ & $(9,375)$ & $3,7992^{* * *}$ & $(9,512)$ \\
\hline életkor & $-0,3900^{* * *}$ & $(14,205)$ & $-0,4145^{* * *}$ & $(13,017)$ \\
\hline Tanul & $-0,1806$ & $(1,335)$ & $-0,1879$ & $(1,309)$ \\
\hline születési év & 0,0031 & $(0,429)$ & 0,0082 & $(1,101)$ \\
\hline születési év X születési év & $-0,0007$ & $(1,303)$ & $-0,0018^{* *}$ & $(3,131)$ \\
\hline Konstans & $-7,5357^{* * *}$ & $(14,465)$ & $-8,9342^{* * *}$ & $(13,933)$ \\
\hline
\end{tabular}

Megjegyzés: A zárójelben szereplő számok a Hubert/Whyte standard hiba becsléseken nyugvó $t$ statisztikák. * $p<0,05 ;{ }^{* *} p<0,01 ;{ }^{* * *} p<0,001$. A megfigyelések (személy-periódusok) súlyozatlan száma a második gyermekvállalást magyarázó modellekben: 45 417. Az egyének száma: 2256. Az egyénszintü véletlenhatás varianciája a szimultán modellben: 0,417. 


\section{ÖSSZEFOGLALÁS}

Jelen tanulmányban az iskolai végzettség és a második gyermekvállalás összefüggését vizsgáltuk. A korábbi kutatások szerint a kapcsolat $U$ alakú: a második gyermek legkisebb eséllyel a középfokú végzettségủ nők körében születik (Husz 2006, Spéder 2006, Bartus et al. 2013, Klesment et al. 2014, Wood - Neels - Kil 2014). Ezek az eredmények eltérnek a nemzetközi tapasztalatoktól és az elméleti várakozásoktól, érdemes tehát megvizsgálni, tényleg U alakú-e a szóban forgó összefüggés, és ha igen, értelmezhető-e valódi oksági kapcsolatként. Három alternatív magyarázatot vettünk figyelembe: a szelekciós magyarázatot, az időprés-hipotézist és a partnerhatás-hipotézist (Kreyenfeld 2002, Bartus et al. 2013).

A kérdéseket az Életünk fordulópontjai panelvizsgálat 1-3. hullámaiból öszszeállított eseménytörténeti adatbázison vizsgáltuk. Eredményeink egyrészt megerősítik a korábbi hazai kutatások eredményeit: az összefüggés tényleg $U$ alakú. Másrészt azt találtuk, hogy az összefüggés valódi. Az U alakú kapcsolat nem módszertani artefaktum: a kapcsolatot akkor is felleljük, ha szimultán eseménytörténeti módszerrel elemezzük a második gyermekvállalást. A diplomás nőkre jellemző gyermekvállalás nem magyarázható az időprés-hipotézissel, mivel az iskolai végzettség nem befolyásolja jelentősen az első gyermekvállaláskori átlagos életkor és a második gyermekvállalás optimális életkorának különbségét. Végül a partnerhatás-hipotézis sem magyarázza az összefüggést. A hipotézis magyarázó ereje akkor lenne maximális, ha a partner iskolázottsága szerint hasonló nők körében nem lenne kapcsolat a második gyermekvállalás és a női iskolázottság között. Eredményeink azonban azt mutatják, hogy a női iskolázottság és a második gyermekvállalás között akkor is $U$ alakú összefüggést találunk, amikor kontrolláljuk a partner iskolai végzettségét. Szintén érdekes eredmény, hogy a második gyermekvállalásnál az számít, van-e felsőfokú végzettsége a partnernek. Ha a párok iskolai végzettségét összevontan vizsgáljuk, azt találjuk, hogy a második gyermekvállalás valószínűsége egyrészt a legfeljebb 8 általános iskolát végzett nők, másrészt a diplomás párok között a legmagasabb. Ez további bizonyíték az U alakú összefüggésre.

Nyitott kérdés, miért van $U$ alakú összefüggés iskolai végzettség és második gyermekvállalás között. A probléma megoldásához támpontot nyújthat a modern közgazdasági elmélet kialakulása. Az elmélet kidolgozásakor Becker (1960) abból indult ki, hogy a gyermek fogyasztási jószág: emiatt a jövedelem növekedésével a gyermekszámnak is növekednie kell. Becker tudatában volt, 
hogy az összefüggés negatív; az elméletet ezért kiegészítette azzal a pótlólagos hipotézissel, miszerint az alacsonyabb jövedelemmel rendelkezők - hiányos ismereteik vagy szűkös erőforrásaik miatt - nem élnek a fogamzásgátlás eszközeivel. Az U alakú összefüggést akkor kapjuk meg, ha feltételezzük: a tudatos családtervezés elmaradásából fakadó pótlólagos termékenységi hatás csak az alapfokú végzettséggel rendelkező nők körében érvényesül. Ez az érvelési stratégia akkor is alkalmazható, ha az elmélet szerint az iskolázottság csökkenti a második gyermekvállalást. Az U alakú kapcsolat levezetéséhez egy olyan pótlólagos hatást kell találni, ami csak a diplomások gyermekvállalását növeli. Nyitott kérdés, mi lehet ez a pótlólagos hatás. Elképzelhető, hogy a szóban forgó pótlólagos hatás a családtámogatási rendszernek köszönhető. A diplomás nők például többet profitálhatnak a gyedből, amelynek bevezetése növelte a termékenységet (Kapitány 2008). A kedvezményes lakáshitelezésnek is a jól kereső és önerővel rendelkező diplomás párok lehetnek a fő haszonélvezői. Ezeknek a magyarázatoknak az ellenőrzését gátolja, hogy az Életünk fordulópontjai felvételben csak keresztmetszetben ismerjük a kérdezettek jövedelmét, így lehetetlen elemezni azt a kérdést, mennyivel változtatják meg a gyermekek után járó juttatások a párok jövedelmi helyzetét.

Az $\cup$ alakú összefüggés ennél szisztematikusabb értelmezését kínálja EspingAndersen és Billari (2015) diffúziós modellje. A modell szerint a nemek családon belüli egyenlősége sztenderd - a logisztikus görbével leírható - diffúziós folyamat keretében terjed el a társadalomban. A második demográfiai átmenet azzal magyarázható, hogy az egalitárius családszerepek elterjedésének üteme nem követte a nők munkaerőpiaci részvételének növekedési ütemét. Emiatt nem alakultak ki a gyermekgondozási feladatokkal kapcsolatos stabil egyensúlyi várakozások azokban a párkapcsolatokban, ahol már a nő is kereső munkát végzett. A diffúziós folyamat felgyorsulása viszont egy másik stabil egyensúlyt hozhat létre, ahol megvalósul a nemek közötti egyenlő munkamegosztás. A gyermekszám és az iskolázottság $U$ alakú összefüggése tehát azzal magyarázható, hogy az érettségizett nők és párjaik között nem alakultak ki olyan stabil várakozások a háztartási és a keresőmunka megosztásával kapcsolatban, mint amilyenek az iskolázatlan és a diplomás nők párkapcsolatait jellemzik. Ennek a magyarázatnak a szisztematikus ellenőrzése természetesen további kutatásokat igényel. 


\section{IRODALOM}

Bartus, Tamás - Murinkó, Lívia - Szalma, Ivett - Szél, Bernadett 2013: The effect of education on second births in Hungary: A test of the time-squeeze, self-selection and partner-effect hypotheses. Demographic Research, 28(1), 1-32.

Bartus Tamás 2015: Lemorzsolódás és súlyozás az Életünk fordulópontjai panelfelvételben. Demográfia, 58(4), 287-308.

Beaujouan, Éva - Solaz, Anne 2008: Childbearing after separation: do second unions make up for earlier missing births? Evidence from France. INED Working Papers, No. 155.

Becker, Gary S. 1960: An economic analysis of fertility. In Universities National Bureau Committee for Economic Research (ed.): Demographic and economic change in developed countries. No. 11. Princeton, NJ, Princeton University Press, 225-256.

Becker, Gary S. 1981: A treatise on the family. Second, enlarged edition. Cambridge, MA, Harvard University Press.

Billingsley, Sunnee 2011: Economic crisis és recovery: Changes in second birth rates within occupational classes and educational groups. Demographic Research, 24(16), 375406.

Blossfeld, Hans-Peter - Huinink, Johannes 1991: Human capital investment or norms of role transition? How women's schooling and career affect the process of family formation. American Journal of Sociology, 97(1), 143-168.

Esping-Andersen, Gøsta - Billari, Francesco 2015: Re-theorizing Family Demographics. Population and Development Review, 41(1), 1-31.

Gerster, Mette - Keiding, Niels - Knudsen, Lisbeth B. - Strandberg-Larsen, Katrine 2007: Education and second birth rates in Denmark 1981-1994. Demographic Research, 17(8), 181-210.

Gustafsson, Siv2001: Optimal age at motherhood. Theoretical and empirical considerations of postponement of maternity in Europe. Journal of Population Economics, 14(2), 225-247.

Happel, Stephen K. - Hill, Jane K. - Low, Stuart A. 1984: An economic analysis of the timing of childbirth. Population Studies, 38(2), 299-311.

Husz Ildikó 2006: Iskolázottság és a gyermekvállalás időzítése. Demográfia, 49(1), 46-67. Jones, Larry E. - Schoonbroodt, Alice - Tertilt, Michele 2011: Fertility theories: Can they explain the negative fertility-income relationship? In Shoven, John B. (ed.): Demography and the economy. University of Chicago Press, Chicago, 43-100.

Kalmijn, Matthijs 1998: Intermarriage és homogamy: Causes, patterns and trends. Annual Review of Sociology, 24(1), 395-421.

Kalmijn, Matthijs - Gelissen, John 2007: The impact of recohabitation on fertility: Evidence from life history data in The Netherlands. Journal of Comparative Family Studies, 38(4), 555-573

Klesment, Martin - Puur, Allan 2010: Effects of education on second births before and after societal transition: Evidence from the Estonian GGS. Demographic Research, 22(28), 891-932. 
Klesment, Martin - Puur, Allan - Rahnu, Leen - Sakkeus, Luule 2014: Varying association between education and second births in Europe: Comparative analyses based on the EU-SILC data. Demographic Research, 31(27), 813-860.

Kapitány Balázs 2008: A „GYED-hatás”: Az 1985 és 1996 közötti családtámogatási rendszer termékenységre gyakorolt hatása. Demográfia, 51(1), 51-78.

Kravdal, Øystein 2001: The high fertility of college educated women in Norway: An artefact of the separate modeling of each parity transition. Demographic Research, 5(6), 187-216.

Kreyenfeld, Michaela 2002: Time-squeeze, partner effect or self-selection? An investigation into the positive effect of women's education on second birth risks in West Germany. Demographic Research, 7(2), 15-48.

Mincer, Jacob - Polachek, Solomon 1974: Family investments in human capital: Earnings of women. Journal of Political Economy, 82(2), S76-S108.

Montgomery, Mark - Trussel, James 1986: Models of marital status and childbearing. In Ashenfelter, Orley C. - Layard, Richard (eds.): Handbook of Labor Economics. Vol. I. Amsterdam, North-Holland, 205-271.

Mureșan, Cornelia - Hoem, Jan M. 2010: The negative educational gradients in Romanian fertility. Demographic Research, 22(4), 95-114.

Spéder, Zsolt 2006: Rudiments of recent fertility decline in Hungary: Postponement, educational differences, and outcomes of changing partnership forms. Demographic Research, 15(8), 253-288.

Taniguchi, Hiromi 1999: The timing of childbearing and women's wages. Journal of Marriage and the Family, 61(4), 1008-1019.

van de Kaa, Dirk J. 2001: Postmodern Fertility Preferences: From Changing Value Orientation to New Behavior. Population and Development Review, 27, Supplement: Global FertilityTransition, 290-331.

Wood, Jonas - Neels, Karel - Kil, Tine 2014: The educational gradient of childlessness and cohort parity progression in 14 low fertility countries. Demographic Research, 31(46), 1365-1416. 


\section{EDUCATION AND SECOND BIRTHS. EVIDENCE FROM THE HUNGARIAN GENERATIONS AND GENDER SURVEY \\ ABSTRACT}

Previous research documented an $U$ shaped relationship between female education and second birth rates in Hungary. In this paper, we examine two questions: (1) how is female education related to second birth rates? And (2) is the relationship in question a causal one? In order to examine causality, we control for sample selection, time-squeeze and partner's education. We use the first three waves of the Hungarian Generations and Gender Survey. We apply discrete-time event history models, estimated jointly for first and second births to control for selection bias. We find that the relationship between female education and second birth rates is indeed $U$ shaped. The relationship seems to be a causal one because it cannot be explained by time-squeeze and partner's education. Analyses using the couple's educational level show that second birth rates are the highest among women with a primary education, on the one hand, and couples with tertiary education, on the other hand. 